\title{
Pengaruh Sambungan Beton Pracetak Hollow Block terhadap Pola Retak yang Timbul
}

\author{
Bunyamin \\ Program Studi Teknik Sipil, Universitas Iskandar Muda, Banda Aceh \\ Jl. Kampus Unida-Surien, Kota Banda Aceh, Telp. (0651) 42225 - 42098 - 42219 \\ *Koresponden email: bunyamin@unida-aceh.ac.id
}

Diterima: 31 Januari 2020

Disetujui: 25 Februari 2020

\begin{abstract}
Hollow block precast concrete which was combined into a beam casting by adding concrete and steel inside and called as "hollow block reinforcement concrete beam". The aim of this research was to knowing the crack pattern due to the connection of hollow block reinforcement concrete beam. The specification of ACI (American Concrete Institute) 211.3R-02 and ASTM (American Society for Testing of Materials) were used in this research. The object were two normal reinforcement concrete beam and two hollow block reinforcement concrete beam with size $15 \mathrm{~cm}$ x $20 \mathrm{~cm}$ x $210 \mathrm{~cm}$. The reinforcement concrete beam was tested by using load cell. The result showed the variety of crack pattern which are flexural crack and flexural-shear crack. For normal reinforcement concrete beam, flexural crack formed at 0.95 ton and flexural-shear crack at 2.83 ton with its duration was 5 minutes and 29 seconds. For hollow block reinforcement concrete beam, flexural crack formed at 1.16 ton and flexural-shear crack at 1.98 ton with its duration was 6 minutes and 8 seconds. The result also showed that hollow block reinforcement concrete beam was more ductile due to crack pattern than normal reinforcement concrete beam.
\end{abstract}

Keywords: Research, crack pattern, hollow block concrete beam, precast concrete, time duration.

\begin{abstract}
Abstrak
Beton pracetak hollow block yang disambung secara monolit dengan menggunakan besi dan beton yaitu balok beton hollow block. Tujuan dari penelitian ini adalah untuk mengetahui pola retak yang terjadi akibat sambungan beton pracetak hollow block. Pedoman ACI (American Concrete Institute) 211.3R-02 dan ASTM (American Society for Testing of Materials) digunakan dalam penelitian ini. Objek yang digunakan adalah 2 (dua) buah balok beton bertulang normal dan 2 (dua) buah balok beton bertulang hollow block dengan ukuran $15 \mathrm{~cm} \times 20 \mathrm{~cm} \times 210 \mathrm{~cm}$. Balok beton bertulang ditest dengan menggunakan alat uji tekan. Hasil menunjukkan pola retak yang timbul beranekaragam yaitu retak lentur dan retak lentur-geser. Untuk balok beton bertulang normal, retak lentur maksimum terbentuk pada saat beban 0,95 Ton dan retak lentur geser maksimum pada saat beban 2,83 Ton dengan waktu 5 menit 29 detik. Untuk balok beton bertulang hollow block, retak lentur maksimum terbentuk pada saat beban 1,16 ton dan retak lentur-geser maksimum pada beban 1,98 Ton dengan waktu 6 menit 8 detik. Dari segi daktilitas, balok beton hollow block mampu berdeformasi terhadap pola retak yang timbul dengan durasi waktu yang lebih lama dibandingkan balok beton bertulang normal.
\end{abstract}

Kata Kunci: Pola retak, balok beton hollow block, beton pracetak, durasi waktu.

\section{Pendahuluan}

Indonesia adalah negara yang rentan terhadap bencana alam sehingga ketika terjadinya bencana alam seperti gempa dan banjir dapat menimbulkan kerusakan bangunan seperti bangunan rumah tinggal. Beton pracetak disebut juga suatu sistem struktur bangunan yang digabung baik dengan menggunakan atau tanpa tulangan [1]. Beton pracetak adalah salah satu bahan bangunan yang digunakan ketika membangun rumah bantuan akibat bencana alam. Beton pracetak yang disambung secara monolit dengan menggunakan besi dan beton ke dalamnya yaitu dinamakan dengan balok dan kolom beton hollow block. Balok dan kolom beton hollow block merupakan struktur utama di dalam membangun rumah bantuan sehingga perlu dilihat kekuatannya. Di dalam penelitian ini, balok beton hollow block yang ditinjau yaitu dari segi pembebanan terhadap retak yang timbul.

Balok beton bertulang adalah salah satu struktur bangunan yang ketika diberikan pembebanan, 
balok berdeformasi terhadap pembebanan yaitu mulai dari lentur, lendut, dan hancur. Selain itu pembebanan pada balok juga menimbulkan retak yang menjadi perhatian khusus di dalam merencanakan balok beton bertulang. Secara umum, retak yang timbul pada balok beton bertulang adalah retak lentur, retak geser, dan retak lentur-geser. Penulangan yang ditambahkan ke dalam balok tersebut sangat berperan dalam memikul beban terhadap retak yang timbul.

Pembebanan pada balok beton hollow block tentunya berdeformasi juga terhadap pembebanan yang diberikan baik dari segi kelenturan, maupun dari keretakan. Beton hollow block digabung dari 7 (tujuh) bagian menjadi satu kesatuan dan dicor dengan menggunakan beton dan tulangan di dalamnya. Pembebanan diberikan secara bertahap hingga balok hancur. Pengaruh sambungan antara satu beton pracetak dengan yang lainnya memberikan dampak yang sangat besar terhadap retak yang timbul dan juga daktilitas yang terbentuk. Pola retak yang timbul beserta durasi waktu yang terjadi dicatat dan dibandingkan dengan balok beton bertulang.

Pengujian balok terhadap 4 (empat) buah benda uji yaitu: Balok Beton Bertulang Atas (BBBA), Balok Beton Hollow Block Atas (BBHBA), Balok Beton Bertulang Bawah (BBBB), dan Balok Beton Hollow Block Bawah (BBHBB). Kapasitas pembebanan adalah load cell dengan beban 50 ton. Penelitian dilaksanakan di Laboratorium Bahan Bangunan dan Struktur Teknik Sipil Universitas Syiah Kuala. Hasil yang dicapai dari penelitian ini adalah jenis retak dan durasi waktu yang terbentuk akibat pembebanan secara eksperimental.

\section{Metode Penelitian}

Penelitian dilaksanakan di Laboratorium Bahan Bangunan dan Struktur Prodi Teknik Sipil Universitas Syiah Kuala yang berpedoman kepada peraturan ASTM (American Society for Testing of Materials) dan ACI (American Concrete Institute). Benda uji yang digunakan adalah sebanyak empat buah yaitu Balok Beton Bertulang Atas (BBBA), Balok Beton Hollow Block Atas (BBHBA), Balok Beton Bertulang Bawah (BBBB), dan Balok Beton HollowBlock Bawah (BBHBB) dengan ukuran adalah $15 \mathrm{~cm} \times 20 \mathrm{~cm} \times 210 \mathrm{~cm}$.

Perencanaan campuran beton normal dan beton hollow block berdasarkan kepada pedoman ASTM [2], ACI 211.1-91 [3] dan ACI 211.3R-02 [4]. Bahan penyusun beton digunakan dalam penelitian ini yaitu semen dengan berat jenis 3,15 , pasir halus lolos saringan $4,76 \mathrm{~mm}$, pasir kasar lolos saringan 9,52 $\mathrm{mm}$, kerikil lolos saringan 25,4 mm, tulangan utama berdiameter $12 \mathrm{~mm}$ dan $10 \mathrm{~mm}$, tulangan sengkang berdiameter $6 \mathrm{~mm}$ serta air PDAM yang tersedia di Laboratorium Bahan Bangunan dan Struktur Prodi Teknik Sipil Universitas Syiah Kuala. Peralatan yang digunakan adalah load cell dengan pembebanan 50 ton, hydraulic jack, monitor komputer beserta data logger.

Pembebanan pada balok beton bertulang akan menghasilkan lendutan dan apabila beban ditingkatkan terus-menerus maka menghasilkan lendutan maksimum hingga balok hancur. Akibat dari pembebanan tersebut akan berpengaruh terhadap kemampuan bahan yang ada dalam balok tersebut untuk berdeformasi pasca kondisi elastis atau disebut dengan daktilitas. Sehingga benda uji beton pracetak mempunyai tingkat daktalitas yang lebih baik dari pada benda uji monolit [5].

Tulangan sengkang pada balok beton hollow block juga diperlukan karena pada dasarnya kuat tekan pada balok terdapat 3 pola retak [6], yaitu:

1. Retak lentur murni (flexural crack), arah retak hampir tegak lurus sumbu balok.

2. Retak geser lentur (flexural shear crack), retak yang terjadi pada bagian balok yang sebelumnya telah terjadi keretakan lentur. Jadi retak geser lentur merupakan perambatan retak miring dari retak yang sudah terjadi sebelumnya.

3. Retak geser murni (shear crack), retak yang terjadi pada daerah dimana gaya geser maksimum bekerja dan tegangan normal sangat kecil.

Metode penelitian pembebanan balok beton hollow block terhadap pola retak dilaksanakan di Laboratorium Bahan Bangunan dan Struktur Prodi Teknik Sipil Universitas Syiah Kuala yang diuraikan sebagai berikut:

A. Pembuatan beton pracetak dengan ukuran lebar dan tinggi adalah $15 \mathrm{~cm}$ x $20 \mathrm{~cm}$ serta panjang $30 \mathrm{~cm}$ [7]. Beton pracetak dibuat dengan mutu beton K-175 dengan bahan di dalamnya terdiri dari semen, agregat halus dan jumlah air yang sangat sedikit tanpa menggunakan agregat kasar. Beton pracetak tersebut memiliki kait di atasnya dan dibawah sehingga dapat disambung dengan beton pracetak lainnya [8]. Cetakan dipersiapkan sesuai dengan ukuran yang ada yaitu $15 \mathrm{~cm}$ x $20 \mathrm{~cm}$ x $30 \mathrm{~cm}$. Perencanaan beton pracetak sesuai dengan pedoman ACI 211.3R-02 dan ASTM. Bahan-bahan penyusun beton pracetak dicampur secara merata di dalam molen sekitar 7 menit. Kemudian 
campuran mortar tersebut dituangkan ke dalam cetakan sampai dengan memenuhi cetakan tersebut. Perencanaan mortar adalah dengan slump mendekati nol, sehingga proses pencetakan hanya memerlukan waktu sekitar 1 jam sudah bisa diangkat cetakannya. Proses pengerasan mortar tersebut maksimal 1 hari dapat langsung digunakan sebagai bahan bangunan untuk beton hollow block. Beton hollow block tersebut dapat dilihat pada Gambar 1.

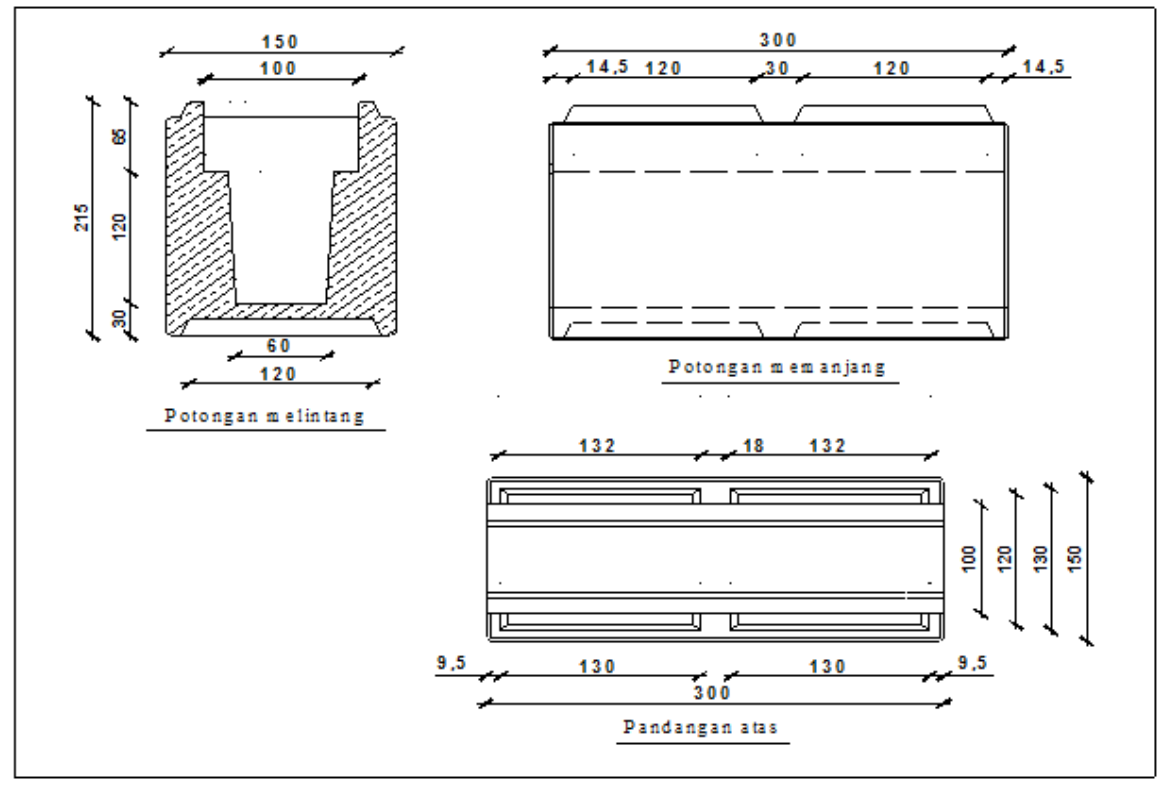

Gambar 1. Beton Pracetak Hollow Block Sumber : [7]

Beton pracetak merupakan beton yang dicetak dengan menggunakan mesin cetak di mana waktu pengerasan dapat tercapai lebih cepat dibandingkan dengan beton konvensional. Beton pracetak adalah beton yang dicetak atau dicor di luar tempat pekerjaan proyek dilaksanakan. Beton pracetak dilakukan pengecoran dan perawatan sesuai dengan pedoman ACI dan SNI (Standard Nasional Indonesia). Beton pracetak yang sudah tercapai umur pengerasan selama satu hari dapat langsung digunakan sebagai balok pracetak beton bertulang [9].

Sistem pemasangan beton pracetak pada pembangunan struktur terdiri dari 3 tiga sistem pemasangan yaitu pemasangan secara konvensional, formwork dan pracetak. Bahan yang digunakan untuk pemasangan secara konvensional adalah terbuat dari kayu dan triplek. Sedangkan pemasangan secara formwork dan pracetak terbuat dari bahan baja ataupun bahan aluminium. Pemasangan bahan tersebut dilaksanakan dengan pengawasan yang ketat supaya menghasilkan kualitas yang baik [9].

Pemasangan beton pracetak tidak hanya diaplikasikan untuk rumah atau asrama saja, namun juga diaplikasikan untuk toko atau gedung perkantoran [10]. Adapun beberapa kelebihan pemasangan beton pracetak sebagai sistem struktur bangunan sebagai berikut:

1. Masa pelaksanaan pekerjaan bangunan di lapangan lebih cepat dan tercapai sesuai dengan yang direncanakan.

2. Biaya yang dilkeluarkan lebih murah

3. Kualitas pekerjaan menjadi lebih baik karena ukuran dan mutu yang dihasilkan seragam

4. Dapat mengurangi jumlah pekerja di lapangan

5. Keadaan di sekitar lapangan menjadi lebih bersih

B. Pembuatan bekisting balok beton bertulang normal dan balok beton bertulang hollow block yaitu sebanyak 4 (empat) buah yang terdiri dari Balok Beton Bertulang Atas (BBBA), Balok Beton Hollow Block Atas (BBHBA), Balok Beton Bertulang Bawah (BBBB), dan Balok Beton Hollow Block Bawah (BBHBB) dengan ukuran adalah $15 \mathrm{~cm}$ x $20 \mathrm{~cm}$ x $210 \mathrm{~cm}$. Posisi penempatan luas tulangan tarik dan tekan berbeda antara balok beton bertulang normal dengan balok beton bertulang hollow block. Bentuk beton pracetak hollow block didalamnya adalah berbentuk segitiga, sehingga digunakan tiga buah tulangan utama di dalamnya. Untuk balok BBBA dan BBHBA, penempatan 
luas tulangan tarik lebih besar dibandingkan dengan luas tulangan tekan dikarenakan beban yang dipikul adalah berasal dari atap. Sedangkan untuk balok BBBB dan BBHBB, penulangan tarik lebih sedikit dibandingkan dengan tulangan tekan, dikarenakan adanya tekanan tanah. Untuk lebih jelasnya dapat dilihat pada Gambar 2.

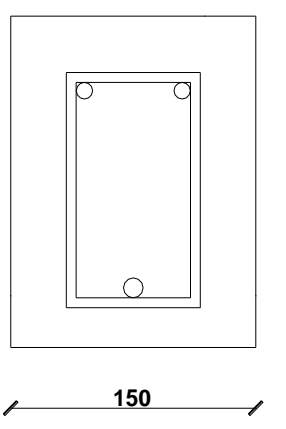

A

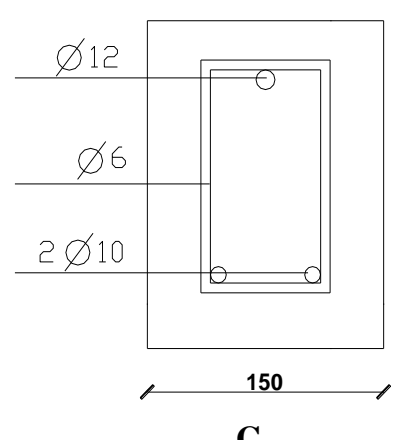

C
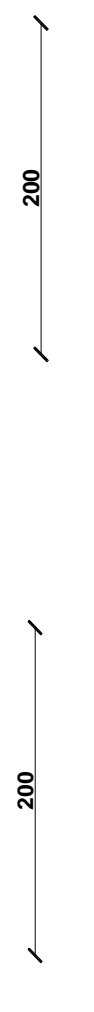

Gambar 2. $\mathrm{A}=\mathrm{BBBA}, \mathrm{B}=\mathrm{BBHBA}, \mathrm{C}=\mathrm{BBBB}, \mathrm{D}=\mathrm{BBHBB}$

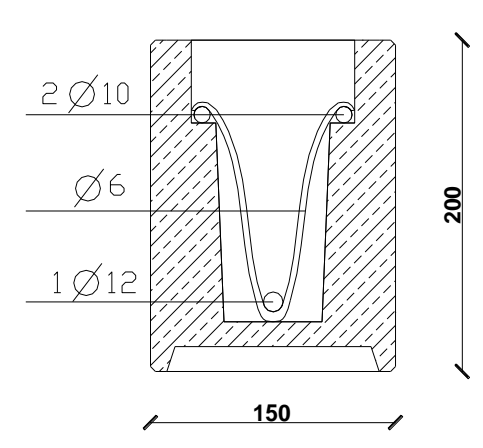

B

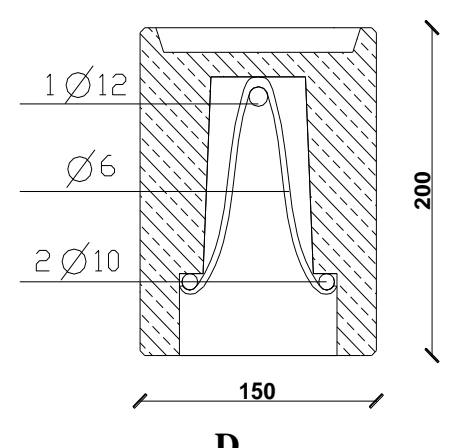

C. Sistem pengecoran balok beton bertulang normal dan beton hollow block dilakukan seperti mana biasanya. Khusus untuk balok beton bertulang hollow block, beton pracetak digabung menjadi satu kesatuan di dalam bekisting seperti pada Gambar 3. Adapun tahapan pengecoran sebagai berikut: mempersiapkan bekisting yang sudah diolesi oli, merangkai besi utama dan sengkang ke dalam bekisting dan kemudian mencampur bahan-bahan penyusun beton secara merata di dalam molen. Campuran beton tersebut dituangkan ke dalam bekisting dengan perlahan-lahan dan dipadatkan serta diratakan sampai terisi penuh ke dalam cetakan tersebut.

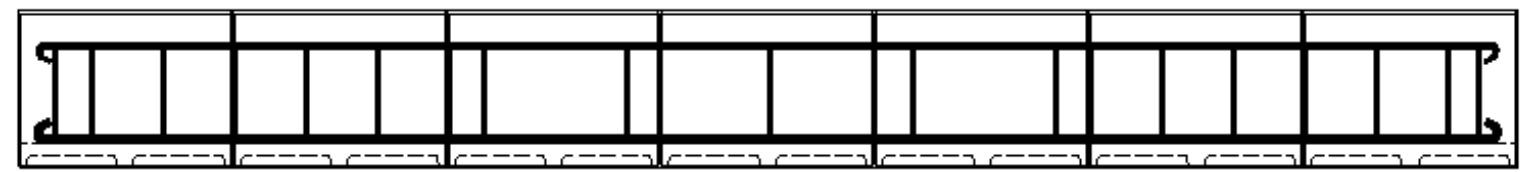

A

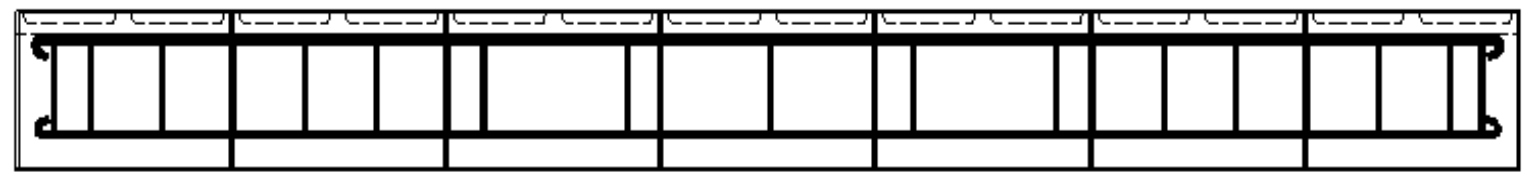

B

Gambar 3. Susunan beton pracetak di dalam bekisting: $A=$ BBHBA, $B=$ BBHBB 
D. Pembukaan bekisting dilakukan setelah satu hari pengecoran

E. Perawatan benda uji balok sebanyak empat buah dilakukan selama 28 hari dengan cara membasahi balok dengan menggunakan goni basah [11].

F. Benda uji balok dites secara ekesperimental di Laboratorium dengan pembebanan load cell yang ditumpu oleh dua tumpuan, di mana pembebanan diberikan tegak lurus dengan sumbu balok [12]. Dari hasil pengujian didapatkan data beban yang dibaca hydraulic jack dan juga pola retak yang terbentuk di bagian depan balok.

G. Pola retak yang terbentuk diukur lebar retaknya dan diamati proses terjadinya retak apakah termasuk ke dalam retak lentur, retak geser, atau retak lentur-geser [13]. Selain itu diukur juga durasi waktu dari awal terbentuknya retak hingga tercapainya retak maksimum dengan tujuan untuk melihat pengaruh sambungan pada beton pracetak terhadap retak yang timbul. Proses kehancuran balok beton bertulang terdiri dari tiga fase yaitu: fase awal yaitu pembebanan pada saat belum terjadinya retak, fase mulai terbentuknya retak, dan fase retak maksimum [14].

Menurut [15], pola keruntuhan beton bertulang dapat diklasifikasikan pada 3 macam:

a) Keruntuhan lentur (Flexural Failure), pada daerah yang mengalami keruntuhan lentur, retak utama terjadi pada tengah bentang dan tegak lurus arah tegangan utama. Retak ini diakibatkan oleh tegangan geser yang sangat kecil dan tegangan lentur yang sangat dominan. Apabila beban terus bertambah, maka retak-retak di tengah bentang bertambah panjang dan semakin lebar, bersamaan dengan semakin besarnya lendutan di tengah bentang. Jika struktur tersebut underreinforced, maka keruntuhan seperti ini ditandai dengan lelehnya tulangan tarik dan diikuti dengan hancurnya beton.

b) Keruntuhan geser (Diagonal Tension Failure), keruntuhan ini ditandai dengan retak-retak halus vertikal di tengah bentang, dan tidak terus menjalar karena kehilangan lekatan antara tulangan dengan beton di sekitarnya pada daerah perletakan. Setelah itu diikuti dengan retak miring yang curam yang menjalar menuju sumbu netral. Kecepatan penjalaran ini semakin berkurang sebagai akibat hancurnya beton pada daerah tekan. Pada saat bertemunya retak miring dengan tepi beton yang hancur, maka terjadilah keruntuhan secara tiba-tiba. Keruntuhan seperti ini harus dihindari karena tidak terjadi peringatan terlebih dahulu.

c) Keruntuhan lentur geser (Shear Compression Failure), Pada keruntuhan ini, retak halus mulai terjadi di tengah bentang berarah vertikal yang diakibatkan oleh lentur. Hal ini diikuti dengan kerusakan lekatan tulangan baja dan beton pada perletakan. Retak diagonal terjadi secara tiba-tiba dekat perletakan dan terus melebar ke retak diagonal utama. Keruntuhan seperti ini tidak memberikan tanda-tanda sebelumnya.

Dari uraian di atas, ketiga tipe keruntuhan pada balok beton bertulang secara umum dapat digambarkan seperti Gambar 4.

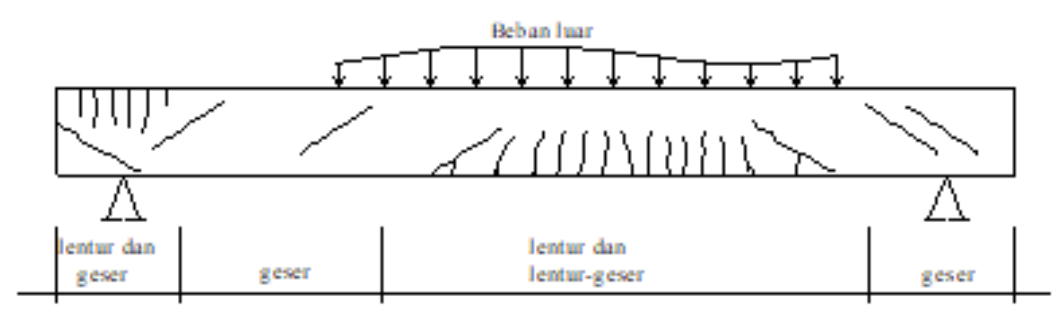

Gambar 4. Pola keruntuhan balok beton bertulang

Pada balok beton bertulang dengan menggunakan sistem pracetak, keruntuhan yang terbentuk pertama kali yaitu pada daerah lentur dan kemudian diikuti dengan keruntuhan di daerah geser. Keruntuhan juga terjadi pada bagian sambungan beton pracetak yaitu terbentuknya retak yang mengakibatkan balok runtuh [14]. Beton pracetak yang disambung menjadi satu kesatuan yang monolit dengan tambahan tulangan dapat berperliku sebagai balok beton bertulang yang daktail [16]. 


\section{Hasil dan Pembahasan}

Penelitian dilakukan di Laboratorium secara eksperimental. Pola retak yang terjadi pada benda uji BBBA dan BBHBA menunjukkan pola retak dengan keruntuhan lentur, sedangkan benda uji BBBB dan BBHBB menunjukkan pola retak lentur-geser. Untuk keruntuhan lentur, pada awal pembebanan terjadi retak lentur pada daerah tengah balok berupa garis-garis yang hampir tegak, kemudian bercabang ke atas pada tahap beban mencapai 50\% - 85\% dari beban maksimum dan terus menuju ke daerah tekan, yang akhirnya menimbulkan lendutan yang besar. Untuk keruntuhan lentur-geser, pada awal pembebanan terjadi retak halus di tengah bentang berarah vertikal yang diakibatkan oleh lentur, kemudian retak diagonal terjadi secara tiba-tiba dekat perletakan, sehingga lebar retak geser semakin bertambah besar seiring dengan penambahan beban dan terus menjalar ke retak diagonal utama sampai menuju pusat pembebanan, yang pada akhirnya mengakibatkan selimut beton bagian atas terkelupas atau hancur.

Pada balok BBBA, pembebanan awal terjadi retak lentur pada beban 0,37 ton, kemudian mulai bercabang pada beban 0,81 ton, retak lentur maksimum terbentuk pada beban 0,95 ton, dengan durasi waktu terjadi retak 7 menit 41 detik. Pada balok BBHBA tidak terjadi retak lentur tetapi terbentuk retak antar celah yang tidak menyebar ke tempat lain, di mana sambungan beton hollow block (antar celah) semakin lama semakin melebar atau merenggang seiring dengan penambahan beban sampai diakhiri dengan lendutan yang semakin besar dengan beban maksimum sebesar 1,16 ton, dengan durasi waktu 7 menit 35 detik. Hasil rekaman foto untuk benda uji BBBA dan BBHBA dapat dilihat pada Gambar 5 dan Gambar 6.
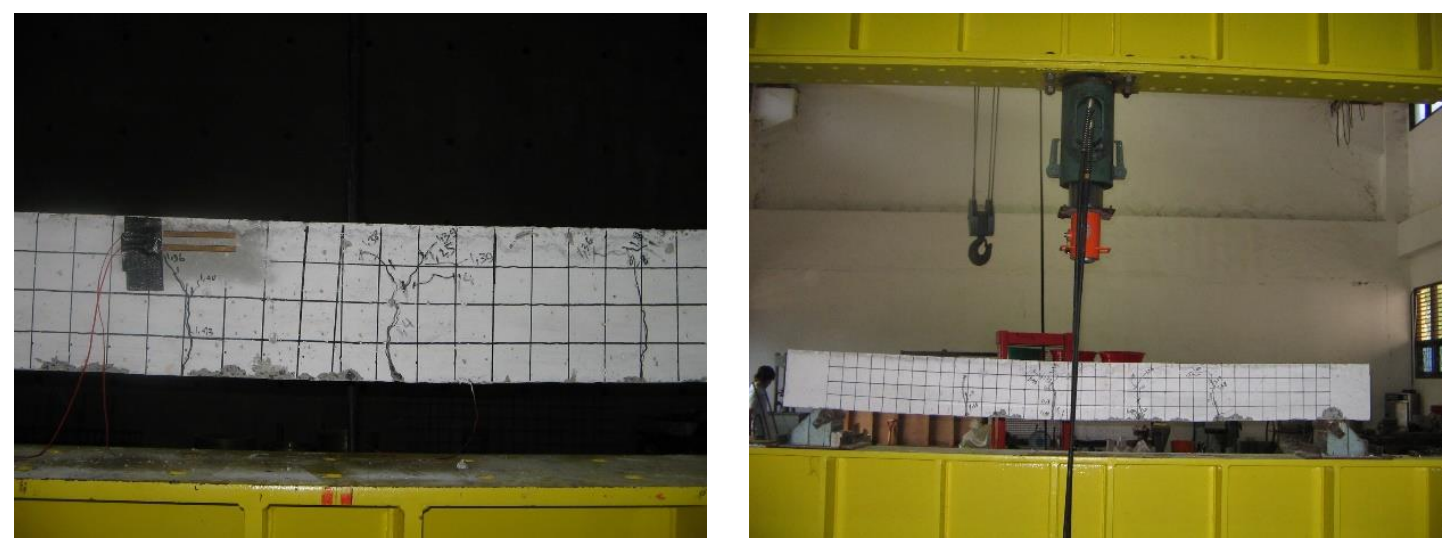

Gambar 5. Pengujian lentur balok BBBA terhadap retak yang timbul
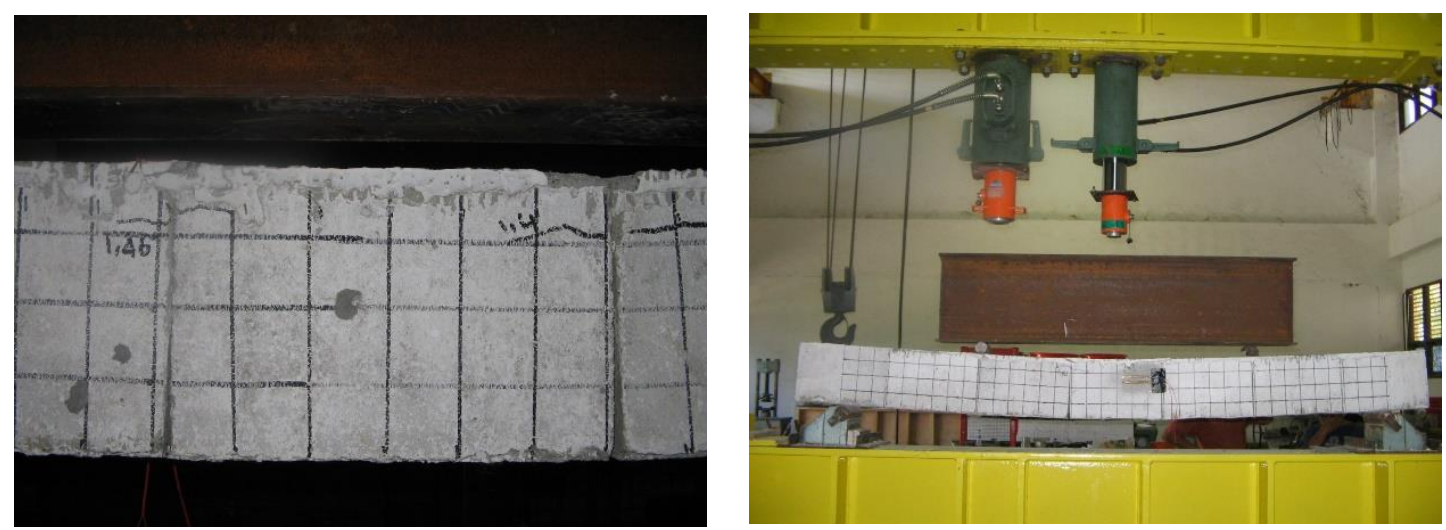

Gambar 6. Pengujian lentur balok BBHBA terhadap retak yang timbul

Pada balok BBBB, pembebanan awal terjadi retak lentur di tengah bentang pada beban 1,1 ton, kemudian mulai berkembang menjadi retak geser pada beban 2,26 ton di dekat tumpuan, retak lenturgeser maksimum terbentuk pada beban 2,83 ton, dengan durasi waktu terjadi retak 5 menit 29 detik. Pada balok BBHBB, pembebanan awal terjadi retak lentur pada beban 1,53 ton, kemudian mulai berkembang menjadi retak geser pada beban 1,80 ton, retak lentur-geser maksimum terbentuk pada beban 1,98 ton, 
dengan durasi waktu terjadi retak 6 menit 8 detik. Hasil rekaman photo untuk benda uji BBBB dan BBHBB dapat dilihat pada Gambar 7 dan Gambar 8.
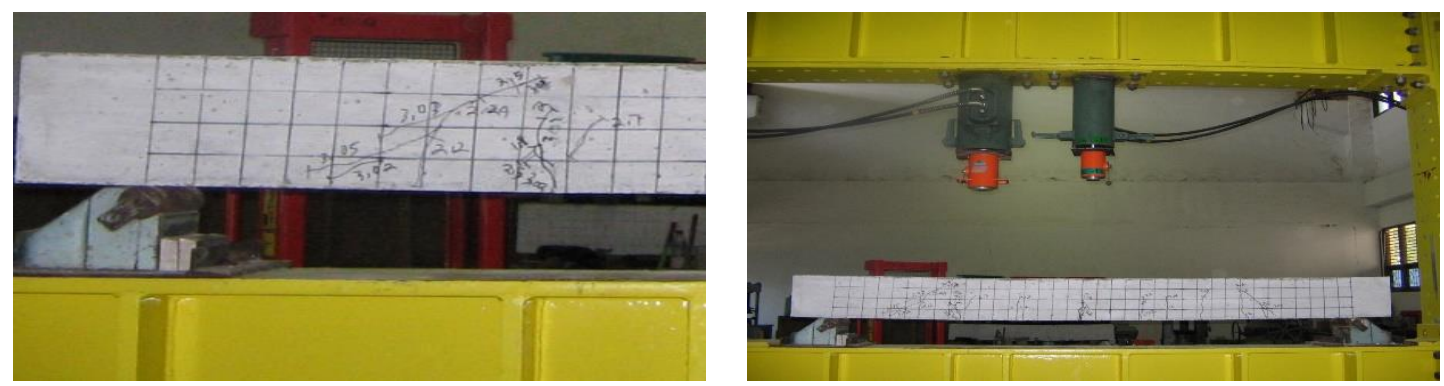

Gambar 7. Pengujian lentur balok BBBB terhadap retak yang timbul
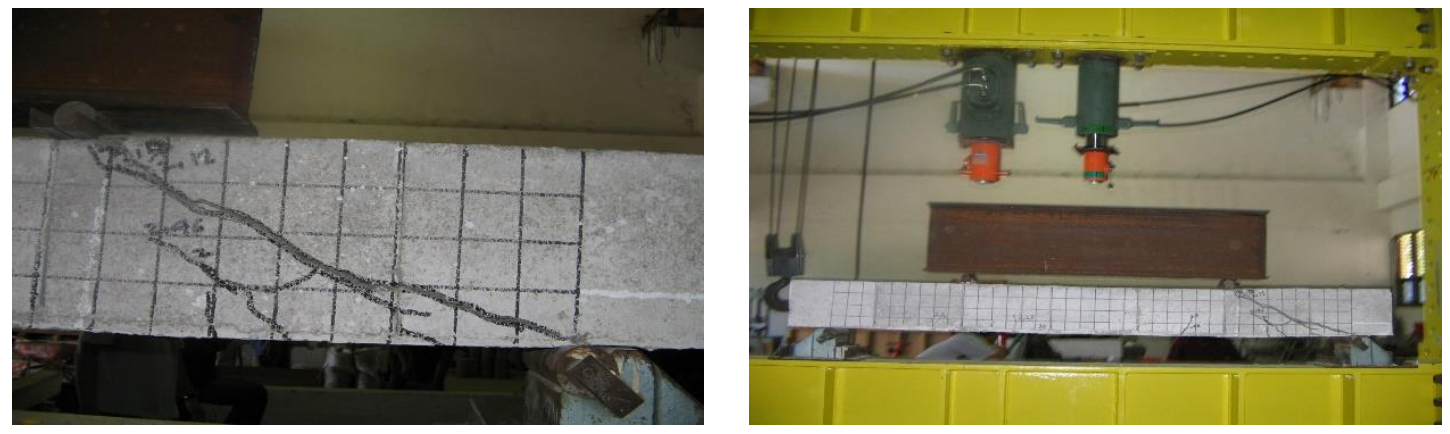

Gambar 8. Pengujian lentur balok BBHBB terhadap retak yang timbul

Hasil pengujian kuat lentur balok di Laboratorium menghasilkan pola retak di sisi depan dan belakang balok yaitu retak lentur dan retak lentur-geser pada balok BBBA, balok BBHBA, balok BBBB, dan balok BBHBB. Pola retak yang terbentuk pada balok digambar kembali dengan menggunakan program AutoCad dengan luasan segmen yang ditinjau adalah sebesar $5 \mathrm{~cm}$ x $5 \mathrm{~cm}$. Hasil pembentukan pola retak pada setiap benda uji balok diperlihatkan pada Gambar 9, 10, 11, dan 12.

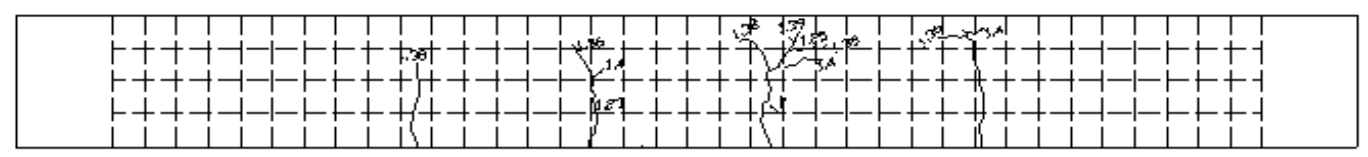

A

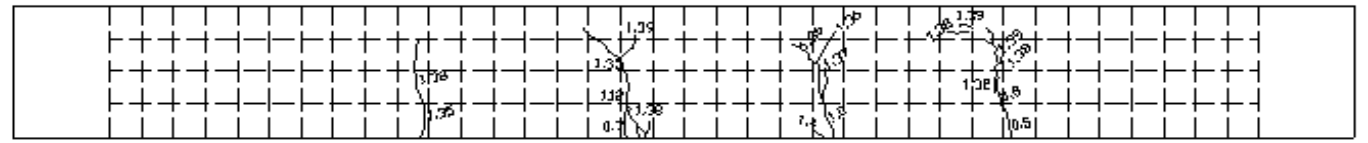

B

Gambar 9. Pola retak pada balok: A = BBBA (sisi depan), B = BBBA (sisi belakang)

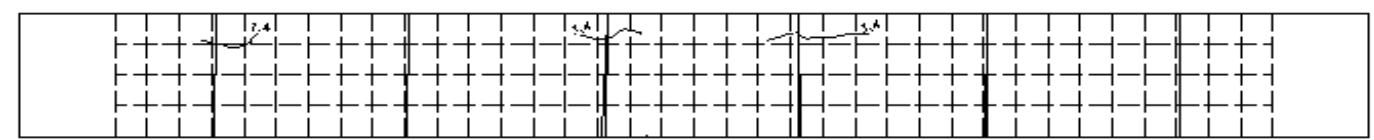

A

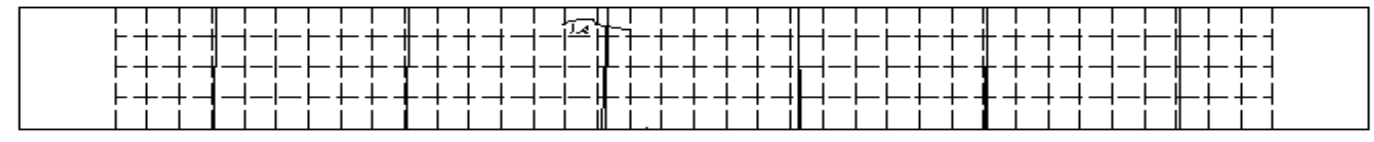

B

Gambar 10. Pola retak pada balok: A = BBHBA (sisi depan), B = BBHBA (sisi belakang) 


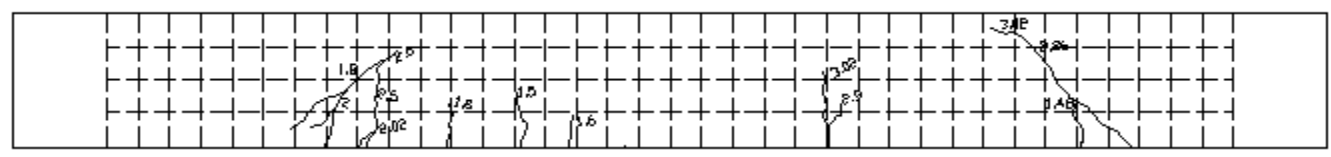

A

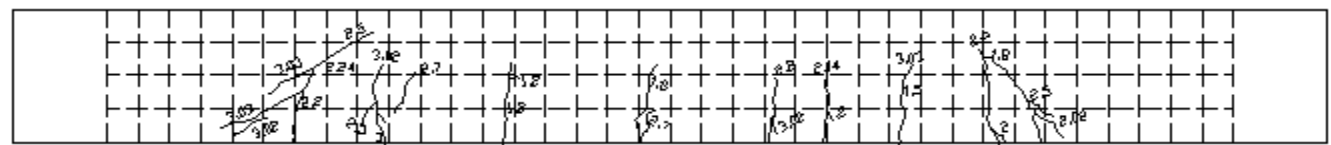

B

Gambar 11. Pola retak pada balok: $A=$ BBBB (sisi depan), $B=$ BBBB (sisi belakang)

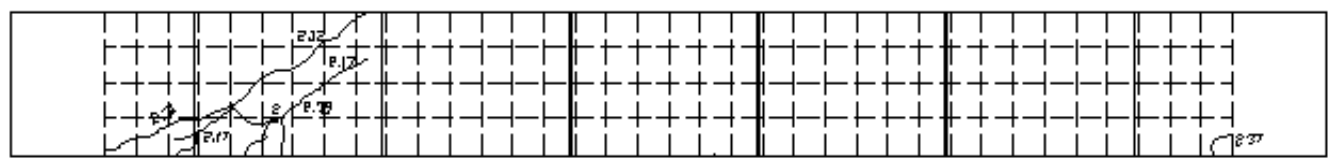

A

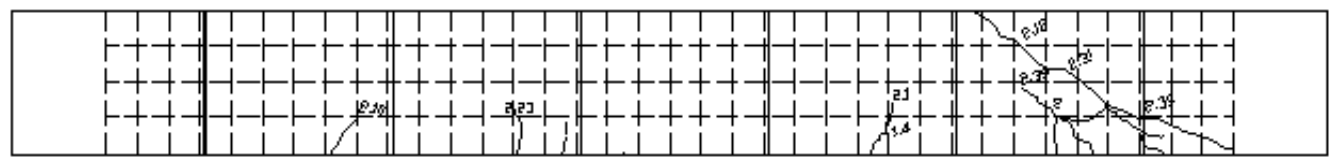

B

Gambar 12. Pola retak pada balok: $A=B B H B B$ (sisi depan), $B=B B H B B$ (sisi belakang)

Hasil pengujian pada balok BBBA dan balok BBHBA menunjukkan bahwa pola retak yang timbul pada sisi depan dan belakang menunjukkan pola retak yang sama. Pada balok BBBA, retak yang timbul pada sisi depan dan belakang adalah sama yaitu retak lentur dan retak lentur-geser. Sedangkan pada balok BBHBA, pola retak yang timbul hanya pada sambungan beton pracetak saja yaitu retak geser. Hal ini dikarenakan posisi tulangan Tarik berjumlah dua buah pada bagian atas yang menerima beban sehingga retak yang timbul hanya bagian atas saja. Untuk balok ring balk, maka pemakaian beton pracetak hollow block lebih daktail dibandingkan dengan beton normal.

Berdasarkan hasil pembentukan pola retak pada Gambar 11 dan Gambar 12 dapat disimpulkan bahwa: pembentukan pola retak dari sisi depan dan belakang balok adalah sama. Untuk balok sloof (BBBB dan BBHBB), penempatan tulangan tarik lebih sedikit dari pada tulangan tekan sehingga terjadinya retak yang sangat besar pada daerah tumpuan balok. Berdasarkan pengamatan di Laboratorium untuk balok BBHBB didapatkan bahwa ketika beban dinaikkan secara bertahap, retak tidak terjadi di tengah bentang dikarenakan adanya sambungan beton pracetak. Sehingga retak yang terjadi dialihkan ke bagian tumpuan dan menyebabkan penjalaran yang besar di bagian tumpuan.

\section{Kesimpulan}

Penelitian ini menghasilkan beberapa kesimpulan diantaranya retak yang timbul pada keempat benda uji balok beton bertulang adalah retak lentur dan retak lentur-geser. Balok beton bertulang normal, retak lentur maksimum terbentuk pada saat beban 0,95 ton dan retak lentur geser maksimum pada saat beban 2,83 ton dengan durasi waktu 5 menit 29 detik. Sementara untuk balok beton bertulang hollow block, retak lentur maksimum terbentuk pada saat beban 1,16 ton dan retak lentur-geser maksimum pada beban 1,98 ton dengan durasi waktu 6 menit 8 detik. Dari segi daktilitas, balok beton hollow block mampu berdeformasi terhadap pola retak yang timbul dengan durasi waktu yang lebih lama dibandingkan balok beton bertulang normal. Pada akhirnya beban yang sanggup dipikul oleh balok beton hollow block lebih kecil dibandingkan balok beton normal.

\section{Saran}

Peneliti merekomendasikan penelitian yang akan datang dengan melihat pengaruh rendaman air laut terhadap sambungan beton pracetak hollow block. Penelitian ke depan juga dapat dilakukan dengan 
menggunakan material yang berbeda yaitu batu pecah untuk menggantikan kerikil dan dilihat terhadap kuat lentur balok. Penelitian dengan menambahkan tulangan tambahan pada sambungan beton pracetak dan dilihat kuat lentur balok tersebut juga bisa dilakukan lebih lanjut.

\section{Daftar Pustaka}

[1] S. Syarifuddin, A. S. Nugraha, P. Sabdono, and R. Y. Adi, "Perencanaan Struktur Rumah Susun Sederhana Sewa Ungaran Menggunakan Beton Pracetak," J. KARYA Tek. SIPIL, vol. 5, no. 2, pp. 170-179, 2016.

[2] I. Standards-Worldwide, “Annual Book of ASTM Standard 2004," Sect. 4, Vol. 04.02, Concr. Aggregates, 2004.

[3] A. C. I. Standard, "Standard practice for selecting proportions for normal, heavyweight, and mass concrete," ACI Man. Concr. Pract., pp. 1-38, 1996.

[4] H. H. Htay, H. T. Aung, and N. M. Kyaw, "Experimental Study on Previous Concrete with Various Mix Ratios," IPTEK J. Proc. Ser., vol. 3, no. 6, 2017.

[5] M. Syarif, "Kajian Eksperimental Balok-Kolom Eksterior Menggunakan Balok Beton Pracetak dan Kolom Komposite (concrete-filled steel column)," Maj. Ilm. Al-Jibra, vol. 12, no. 41, 2011.

[6] Y. T. Dady, M. D. J. Sumajouw, and R. S. Windah, "Pengaruh Kuat Tekan Terhadap Kuat Lentur Balok Beton Bertulang," J. SIPIL STATIK, vol. 3, no. 5, 2015.

[7] T. Boen, Manual bangunan tahan gempa (rumah tinggal). 1978.

[8] Bunyamin, "Comparison of deflection of hollow block concrete blocks with normal reinforced concrete beam," in AIP Conference Proceedings, 2019, vol. 2059, no. 1, p. 20039.

[9] N. M. Sianturi, "Tinjauan Penggunaaan Balok Pracetak Pada Pembangunan Gedung," J. Ranc. Sipil, vol. 1, no. 1, pp. 10-20, 2012.

[10] S. A. Nurjannah, "Perkembangan Sistem Struktur Beton Pracetak Sebagai Alternatif pada Teknologi Konstruksi Indonesia yang Mendukung Efisiensi Energi serta Ramah Lingkungan," 2011.

[11] Mulyono, "Teknologi Beton," Yogyakarta Andi Offset, 2004.

[12] S. Prayitno, E. Rismunarsi, and A. Asidiq, "Pengaruh Panjang Sambungan Lewatan Tulangan Baja Polos Pada Balok Beton Bertulang Terhadap Uji Lentur," Matriks Tek. Sipil, vol. 4, no. 4, 2016.

[13] O. F. Nur, "Kajian Eksperimental Perilaku Balok Beton Tulangan Tunggal Berdasarkan Tipe Keruntuhan Balok," J. Rekayasa Sipil, vol. 5, no. 2, pp. 39-52, 2009.

[14] K. N. Cahyani, "Kajian Eksperimental Pola Retak Pada Sambungan Balok-Kolom Beton Pracetak Dengan Menggunakan Sambungan Kering," Prokons J. Tek. Sipil, vol. 13, no. 1, pp. 27-30, 2019.

[15] E. G. Nawy, T. Surjaman, and B. Suryoatmono, Beton bertulang: suatu pendekatan dasar. PT. Eresco, Bandung, 1990.

[16] R. Simbolon, H. Parung, R. Irmawaty, and A. Amiruddin, "Daktilitas Sambungan Model Takikan Rangkap Pada Hubungan Balok-Kolom Beton Pracetak, Akibat Beban Lateral Siklik," J. Spektran, vol. 7, no. 2, 2019. 